\title{
HISTORY OF DREDGING AND FILLING OF LAGOONS IN THE SAN JUAN AREA, PUERTO RICO
}

\section{U.S. GEOLOGICAL SURVEY \\ Water-Resources Investigations 38-76}

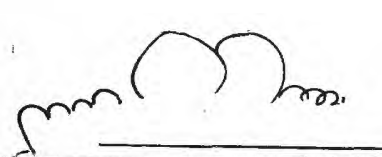

$$
\text { Pormon }
$$

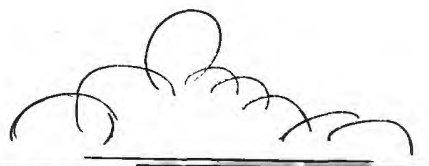

OCEANO ATLANTICO

\section{s.t.t.t.}

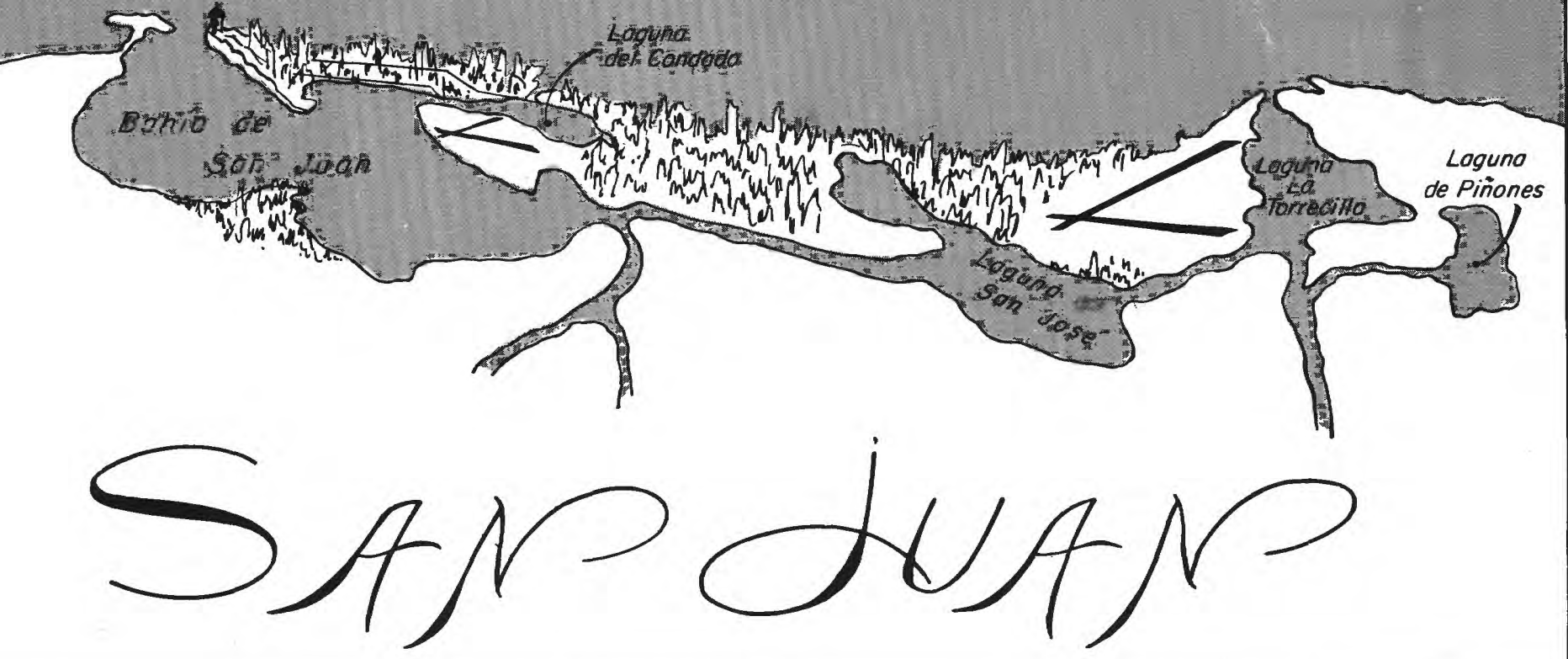

Prepared in cooperation with the COMMONWEALTH OF PUERTO IICO

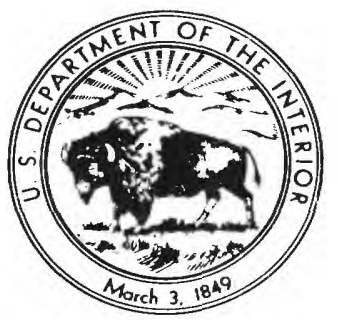




\begin{tabular}{|c|c|c|}
\hline $\begin{array}{l}\text { BIBLIOGRAPHIC DATA } \\
\text { SHEET }\end{array}$ & I. Report No. & 3. Fecivents Accession No \\
\hline \multirow{2}{*}{\multicolumn{2}{|c|}{$\begin{array}{l}\text { 4. Tille ond Subtirle } \\
\qquad \text { History of dredging and filling of lagoons } \\
\text { in the San Juan area, Puerto Rico }\end{array}$}} & $\begin{array}{l}\text { 5. Report Date } \\
\text { September } 1976\end{array}$ \\
\hline & & 6. \\
\hline \multicolumn{2}{|c|}{ S. R. Ellis } & $\begin{array}{l}\text { 8. Performing Organizotion Report } \\
\text { No USGS/WRI } 38-76\end{array}$ \\
\hline \multirow{2}{*}{\multicolumn{2}{|c|}{$\begin{array}{l}\text { 9. Performing Orgonizotion Nome and Address } \\
\qquad \begin{array}{l}\text { U. S. Geological Survey -- Water Resources Division } \\
\text { P. O. Box } 34168 \\
\text { Ft. Buchanan, Puerto Rico } 00934\end{array}\end{array}$}} & 10. Project/Tosh/Work Unit No. \\
\hline & & II. Controct/Gront No. \\
\hline \multirow{2}{*}{\multicolumn{2}{|c|}{$\begin{array}{l}\text { 12. Sponsoring Orgonization Name and Addross } \\
\qquad \begin{array}{l}\text { U. S. Geological Survey -- Water Resources Division } \\
\text { P. O. Box } 34168 \\
\text { Ft. Buchanan, Puerto Rico } 00934\end{array}\end{array}$}} & $\begin{array}{l}\text { 13. Type of Report \& Period } \\
\text { Covered } \\
\text { Interim }\end{array}$ \\
\hline & & 14. \\
\hline
\end{tabular}

15. Suplementary Notes

Prepared in cooperation with the Commonwealth of Puerto Rico

16. Absiracis

Laguna La Torrecilla, Laguna de Piñones, Laguna San José, and Laguna del Condado, in the San Juan, Puerto Rico area, are located within a metropolitan area of more than 1 million people. Bathymetric maps made during the study, in 1973, showed that Lagunas La Torrecilla, San José, and del Condado have been modified by dredging and filling; whereas, Laguna de Piñones has remained in a near natural state. Laguna La Torrecilla has been dredged to a depth, in places, of about 18 metres, and Lagunas San José and del Condado, in places to about 11 metres. Dredging in the San Juan lagoons has been harmful, beneficial, and in a few instances has had little or no noticeable effect on the water quality. Usually, dredging in the connecting canals has been beneficial if the water entering the lagoons through the canals was of better quality than the water in the lagoon. Dredging in the mouths of lagoons has been beneficial; whereas, filling or blocking the mouths has been harmful.

17. Key words and Document Analysis

170. Descriptors

*Lagoons, *Bathymetry, *Dredging, *Canals, *Puerto Rico, Water quality, Flow.

17b. Identifiers/Open-Ended Torms

Laguna La Torrecilla, Laguna de Piñones, Laguna San José, Laguna del Condado.

17c. COSATI FIUId/Group

18. Avoilobility Stotement

No restriction on distribution

\begin{tabular}{|c|c|}
\hline $\begin{array}{c}\text { 19. Security Closs (This Report) } \\
\text { UNCLASSIFIED }\end{array}$ & $\begin{array}{c}\text { 21. No. of Poges } \\
30\end{array}$ \\
\hline $\begin{array}{c}\text { 20. Security Closs (This Poge) } \\
\text { UNCLASSIFIED }\end{array}$ & \begin{tabular}{l} 
22. Price \\
\hline
\end{tabular} \\
\hline
\end{tabular}


HISTORY OF DREDGING AND FILLING

OF LAGOONS IN THE SAN JUAN AREA,

PUERTO RICO

By S. R. Ellis

U.S. GEOLOGICAL SURVEY

Water-Resources Investigations 38-76

Prepared in cooperation with the

Commonweal th of Puerto Rico

September 1976 


\section{UNITED STATES DEPARTMENT OF THE INTERIOR}

Thomas S. Kleppe, Secretary

GEOLOGICAL SURVEY

V. E. McKelvey, Director

For additional information write to:

U.S. Geological Survey -- WRD

P.0. Box 34168

Ft. Buchanan, Puerto Rico 00934 


\section{CONTENTS}

Page

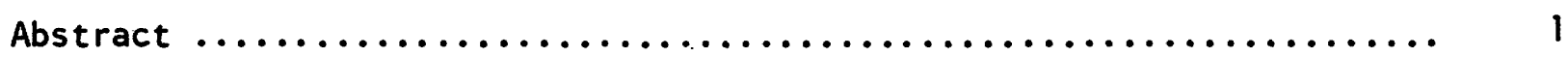

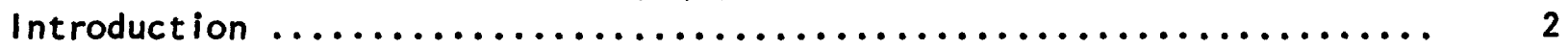

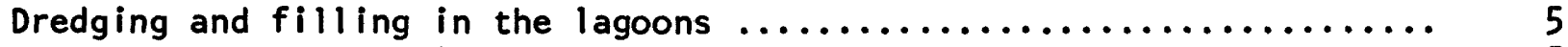

Laguna La Torrecilla .................................. 5

Laguna San José $\ldots \ldots \ldots \ldots \ldots \ldots \ldots \ldots \ldots \ldots \ldots \ldots \ldots \ldots \ldots \ldots \ldots \ldots \ldots \ldots \ldots, 15$

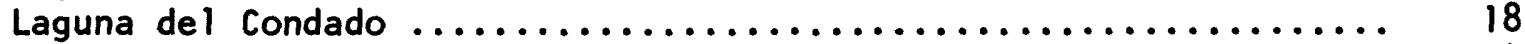

Summary and conclusions $\ldots \ldots \ldots \ldots \ldots \ldots \ldots \ldots \ldots \ldots \ldots \ldots \ldots \ldots \ldots \ldots, 24$

Selected references $\ldots \ldots \ldots \ldots \ldots \ldots \ldots \ldots \ldots \ldots \ldots \ldots \ldots \ldots \ldots \ldots, 25$ 


\section{ILLUSTRATIONS}

Page

Figure 1. Map of San Juan lagoon project area showing location and general features ................... 3

Figures 2-5. Bathymetric maps of:

2. Laguna La Torrecilla ........................ In pocket

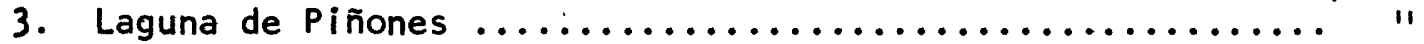

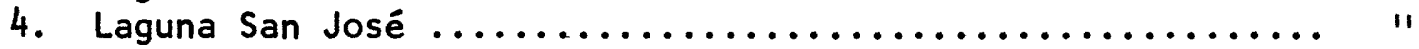

5. Laguna del Condado .............................. "

Figures 6-11. Maps of Laguna La Torrecilla showing: .

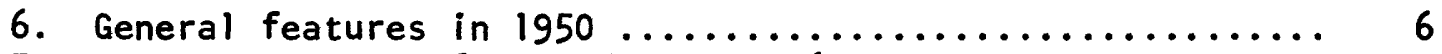

7. Areas dredged or filled from $1950-62 \ldots \ldots \ldots \ldots \ldots \ldots \ldots, 7$

8. Areas dredged or filled from $1962-67 \ldots \ldots \ldots \ldots \ldots \ldots \ldots .8 .6$.

9. Areas dredged or filled from $1967-71 \ldots \ldots \ldots \ldots \ldots \ldots . . . . .10$

10. Comparison of 1950 and 1971 shorelines and areas of internal dredging $\ldots \ldots \ldots \ldots \ldots \ldots \ldots, 11$

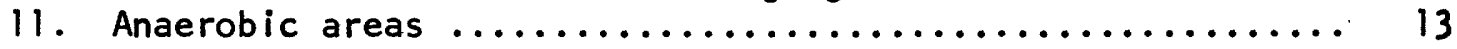

Figure 12. Profiles of dissolved oxygen, temperature and specific conductance for two sites in Laguna La Torrecilla which are anaerobic below 2 metres ............................. 14

Figures 13-15. Maps of Laguna San José showing:

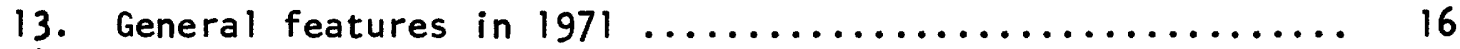

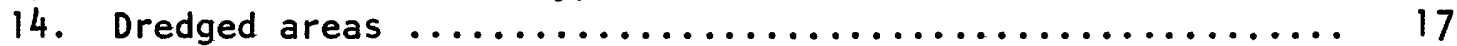

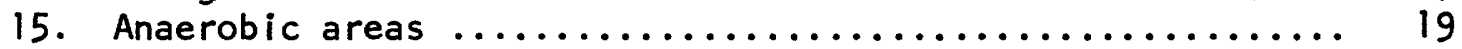

Figure 16. Profiles of dissolved oxygen, temperature, and specific conductance at selected sites in Laguna San José

Figures 17-19. Maps of Laguna del Condado showing:

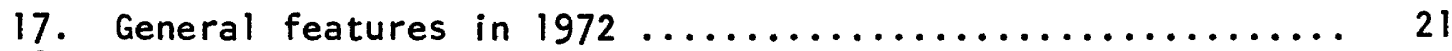

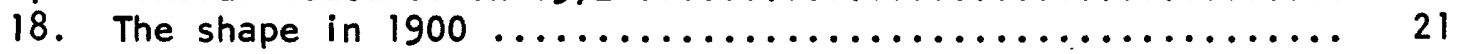

19. Comparison of 1900 and 1972 shorelines and areas of internal dredging $\ldots \ldots \ldots \ldots \ldots \ldots \ldots \ldots$ 


\section{HISTORY OF DREDGING AND FILLING OF}

LAGOONS IN THE SAN JUAN AREA,

PUERTO RICO

By S. R. Ellis

\section{ABSTRACT}

Laguna La Torrecilla, Laguna de Piñones, Laguna San José, and Laguna del Condado; in the San Juan, Puerto Rico area: are located within a metropolitan area of more than 1 million people. A study of the hydrology of the lagoons was started July 1973 by the U.S. Geological Survey.

Bathymetric maps made during the study, in 1973, showed that Lagunas La Torrecilla, San José, and del Condado have been modified by dredging and filling; whereas, Laguna de Piñones has remained in a near natural state. Laguna La Torrecilla has been dredged to a depth, in places, of about 18 metres, and Lagunas San José and del Condado, in places to about 11 metres.

Dredging in Laguna La Torrecilla may have removed about 3.1 million cubic metres of material. The dredging has occurred in about 25 percent of the lagoon and increased the volume of the lagoon by about 110 percent of the original. Filling along the shorelines has reduced the area of the lagoon by about 10 percent. Boca de Cangrejos, the mouth of Laguna La Torrecilla, has been dredged as has Canal Suárez, the connection with Laguna San José. The dredging of the mouth has caused an increased flow through Boca de Cangrejos. The combination of dredging and sewage-treatment plant effluent have produced anaerobic conditions, below 2 metres, in the southeastern end of Laguna La Torrecilla.

Dredging in Laguna San José, removing about. 3 million cubic metres of material, has occurred in about 17 percent of the area of the lagoon, and has increased the volume to about 130 percent of its original amount. The construction of Canal Suárez, before 1900, and subsequent deepening and widening has increased the flow of brackish water into Laguna San José, probably reducing the renewal time. All dredged areas, below 2.5 metres deep, are anaerobic.

Laguna del Condado has been divided into two parts by the construction of Avenida Ashford Bridge. Dredging has removed about 280,000 cubic metres of material, and filling has occurred along almost the entire shoreline. 
Dredging in the San Juan lagoons has been harmful, beneficial, and in a few instances has had little or no noticeable effect on the water quality. Usually, dredging in the connecting canals has been beneficial if the water entering the lagoon through the canals was of better quality than the water in the lagoon. Dredging in the mouths of lagoons has been beneficial; whereas, filling or blocking the mouths has been harmful.

\section{INTRODUCTION}

The San Juan lagoons are located in northeastern Puerto Rico in a metropolitan area of over 1 million people. A comprehensive study of the lagoon system was begun July 1973 by the U.S. Geological Survey, in cooperation with the Puerto Rico Environmental Quality Board and the Department of Natural Resources.

Many stresses are placed on the lagoons: discharge of sewage and urban runoff; building of new land areas for houses, highways, and landfills; and excavating of sand and fill material.

Presented in this report are brief historical accounts of the physical changes that have occurredin the lagoons as the result of dredging and filling between 1950 and 1974. In addition examples are given of the impact on water quality (the recycling of nutrients from anaerobic zones) resulting from the combination of the major stresses (dredging, sewage effluent, and urban runoff) placed on the lagoons.

'The San Juan lagoons consist of Lagunas La Torrecilla, de Piñones, San José, and del Condado (fig. 1). This coastal area is a gentle sloping plain covered by deposits of sand, silt, clay, and muck (Anderson, 1974). Parts of the lagoons contain sand of construction quality that can be easily extracted by dredging (Environmental Research and Application, 1972).

Inflow to and outflow from Lagunas La Torrecilla, de Piñones, and San José, which are connected by canals, are controlled by tidal stage primarily through Boca de Cangrejos with minor inflow and outflow through Caño de Martín. Peña. There is little natural flow to the lagoons from streams except during storm runoff. Much of the flow of Quebrada Blasina is effluent from sewage treatment plants. Low flow in the other streams, which drain predominanily urban areas, is from storm and sewage outfalls discharging to the streams. In addition storm and sewage outfall also discharge directly to Lagunas San José and La Torrecilla, Caño Martín Peña and Canal Suárez (Elli is and Gómez-Gómez, $1976 a$, b). A positive outflow component from Laguna San José is attributed to leakage from a freshwater artesian aquifer that underlies the lagoon (Ellis and Gómez-Gómez, 1976a; Anderson,-1974). Although Laguna del Condado shows tidal fluctuations, flow generally is one way from the sea to Caño de San Antonio due to a reef that deflects a westerly flowing ocean current into the mouth of the lagoon. 


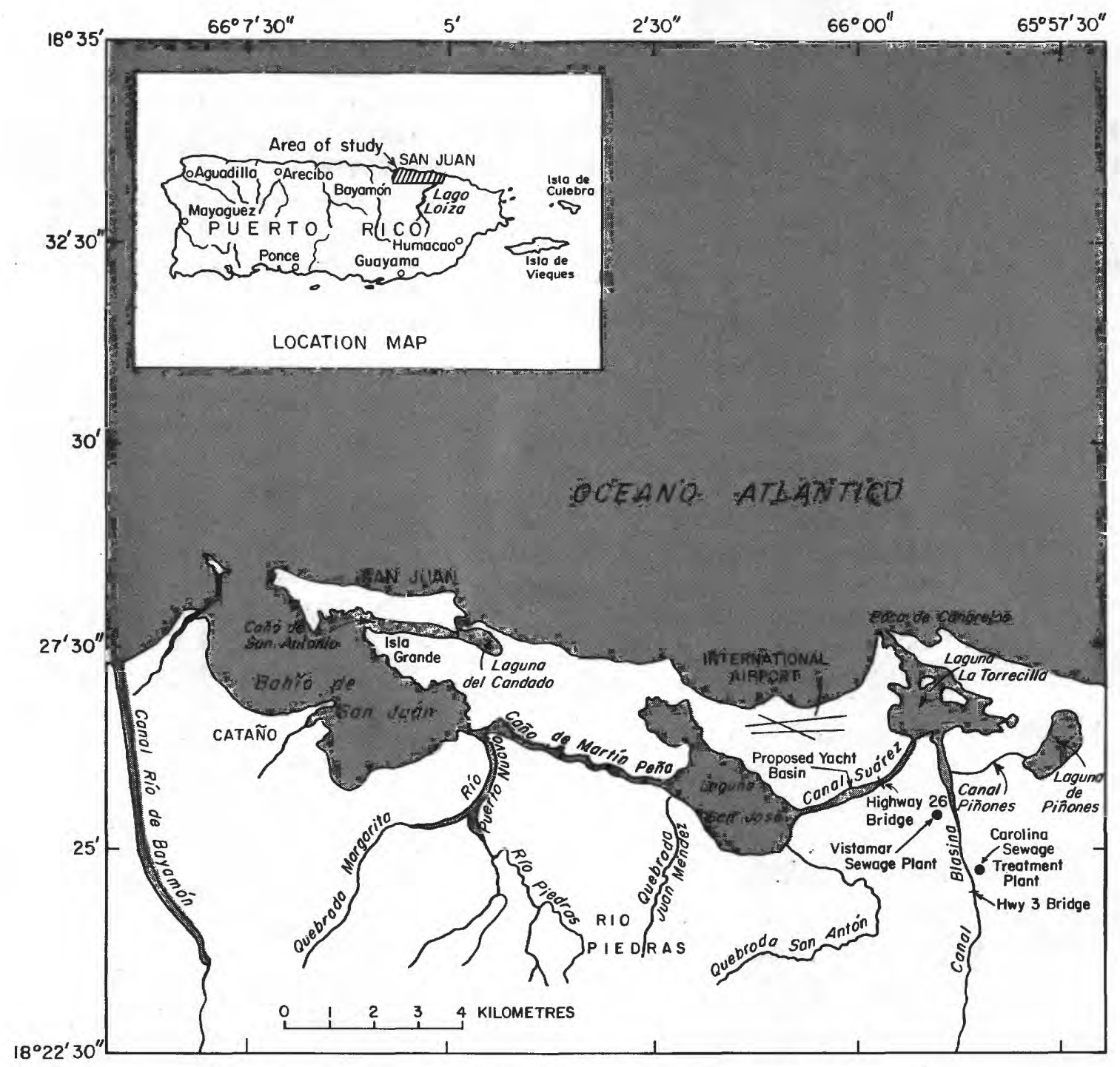

Figure 1.--San Juan Lagoon project area showing location and general features.

In 1973 there were no bathymetric maps of Lagunas La Torrecilla, de Piñones, or San José, and only an outdated map was available for Laguna del Condado. Hence, the extent of any changes that had occurred in the lagoons was not known. In order to evaluate the impact of dredging and filling, bathymetric maps were needed. The base maps used to plot the data obtained in a bathymetric survey were U.S. Geological Survey topographic maps enlarged and corrected for recent changes on the basis of 1972 aerial photographs.

A bathymetric survey was made on each lagoon in 1973 and repeated as a check in late 1973 and early 1974 by the following method. A portable recording fathometer was coupled to an 0tt current meter through a counter which provided range marks on the fathometer chart at preselected distances. An aeronautical. compass and visual sighting were used during each traverse across the lagoon to obtain headings and to keep the boat operator on line with the heading. A log sheet was kept for each run, noting time, directions and landmarks. These notes, along with data from stage and tidal records, were used in correcting the maps to mean lagoon level (figs. 2-5). The depths of the water were plotted for each run on the maps and lines of equal water depth were drawn.

The maps (figs. 2-5) are not intended to be used for navigation. 
Aerial photographs were available for the years 1951, 1962, 1967, 1971 and 1973 for Lagunas La Torrecilla, San José, and de Piñones; 1951, 1971, and 1973* for Laguna del Condado. These aerial photographs were used to establish periods when dredging or filling had occurred. In some of the photographs, dredging operations were visible, and others showed the outline of dredged areas. Interviews. with local residents supplied additional information as to dates and extent of dredging during certain time spans.

The lagoons were assumed to have uniform depths prior to dredging. The assumed predredged bottom configuration was compared with the bathymetric maps and dredged areas were determined. The aerial photographs and topographic maps were used to determine shoreline changes.

Comparison of the aerial photographs showed no noticeable change had occurred in the lagoons between 1971 and 1973, when the bathymetric maps were made. No dredging or filling has taken place in the lagoons from 1973 to January 1975, except in Laguna del Condado, in 1974, south of Avenida Ashford Bridge. This dredging removed a sandbar, which has built up again since dredging operations ceased in the summer of 1974.

A summary of changes in area and volume of the lagoons is given below.

\begin{tabular}{|c|c|c|c|c|}
\hline Lagoon & Year & Area, in ha & Volume, & in $10^{6} \mathrm{~m}^{3}$ \\
\hline Torrecilla & $\begin{array}{l}1950 \\
1962 \\
1967 \\
1974\end{array}$ & $\begin{array}{l}282 \\
255 \\
260 \\
258\end{array}$ & $\begin{array}{l}2.8 \\
3.1 \\
5.0 \\
5.91\end{array}$ & $\begin{array}{l}(e) \\
(e) \\
(e)\end{array}$ \\
\hline San José & $\begin{array}{l}1950 \\
1974\end{array}$ & $\begin{array}{l}547 \\
547\end{array}$ & $\begin{array}{l}10.2 \\
13.2\end{array}$ & (e) \\
\hline Condado & $\begin{array}{l}1900 \\
1974\end{array}$ & $\begin{array}{l}50 \\
31\end{array}$ & $\begin{array}{l}1.1 \\
1.42\end{array}$ & (e) \\
\hline
\end{tabular}

(e) Estimated 
Dredging and filling has occurred in Lagunas La Torrecilla, San José, and del Condado. The shape and size of Laguna de Piñones has remained in a near natural condition. Probably the first manmade alteration of these lagoons was a bridge built across Laguna del Condado, before 1625 by the Spanish. Dredging before 1900 occurred when a series of canals were dug connecting the area east of Laguna de Piñones to Laguna San José by way of Laguna La Torrecilla (Puerto Rico Reconstruction Authority, 1940). This canal system was used to transport local produce to markets in San Juan, but presently only remnants of the channels are visible in the Laguna de Piñones area.

\section{Laguna La Torrecilla}

The base map (fig. 6) used for the purpose of determining changes in Laguna La Torrecilla was the U.S. Geological Survey topographic map, Carolina, Puerto Rico, prepared in 1950, to a scale of 1:30,000. This map was compared with aerial photographs for the years 1951, 1962, 1967, and 1971. On the basis of a field inspection, no noticeable changes have occurred in Laguna La Torrecilla from 1971 to January 1975.

A comparison of the 1950 topographic map and the 1951 aerial photograph shows only two changes. One is that a second bridge was constructed across Boca de Cangrejos, at the site of the present bridge. The second is that some filling and possibly some dredging of the lagoon edge have been done at the then future site of the Isla Verde International Airport.

The 1962 aerial photographs show changes in three areas of Laguna La Torrecilla (fig. 7). The old bridge across the lagoon was removed. The inlet channel was widened and deepened, and an area on the west shore was dredged to provide space for the Cangrejos Yacht Club marina. A rectangular area of mangroves on the east shore of the inlet channel also was dredged. This dredging may have been the source of the fill placed on the west edge of the lagoon to provide additional land for the Isla Verde International Airport. Dredging was in progress in 1962 in the south end of the lagoon. This dredging formed a lake in the shape of a right triangle with a connecting canal to the lagoon. The lake serves as a boat basin for the then future Vistamar Marina housing development.

The map corrected from the 1967 aerial photographs (fig. 8) shows that the south end of Laguna La Torrecilla was further changed. Vistamar Marina was constructed in an area that was previously a mangrove swamp. The lagoon to the immediate north of the development was dredged to about $12 \mathrm{~m}$ in places to provide fill; see figure 2. Canal Suárez was enlarged and deepened. A basin for future use as a yacht harbor was formed in the canal on the west side of Highway 26 (fig. 1). The dredged material was probably used for fill along both banks of Canal Suárez and for construction of a second runway at Is la Verde International Airport. 


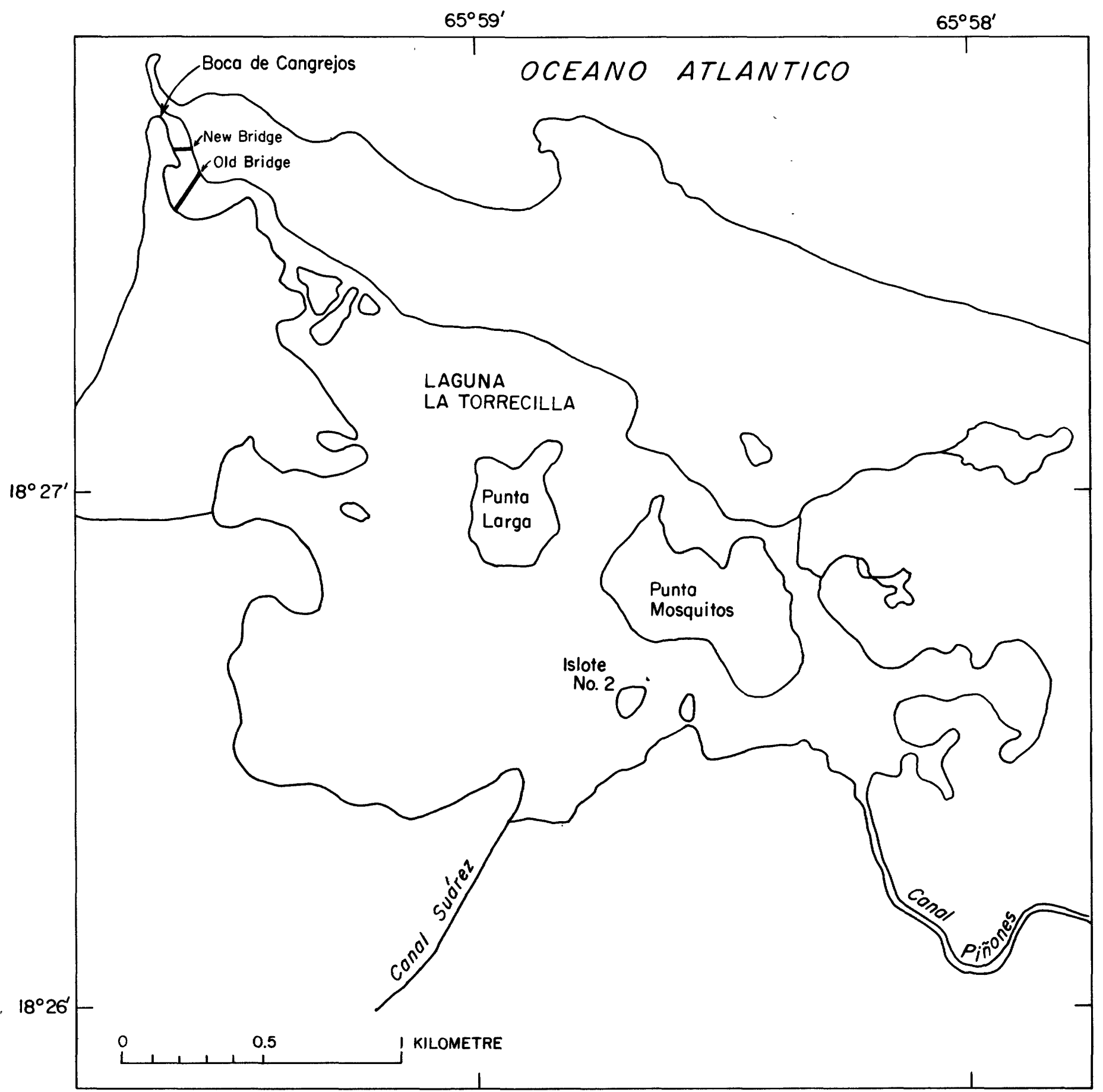

Base from U.S. Geological Survey

Carolina, 1:30,000, 1950

Figure 6.--General features of Laguna La Torrecilla in 1950. 


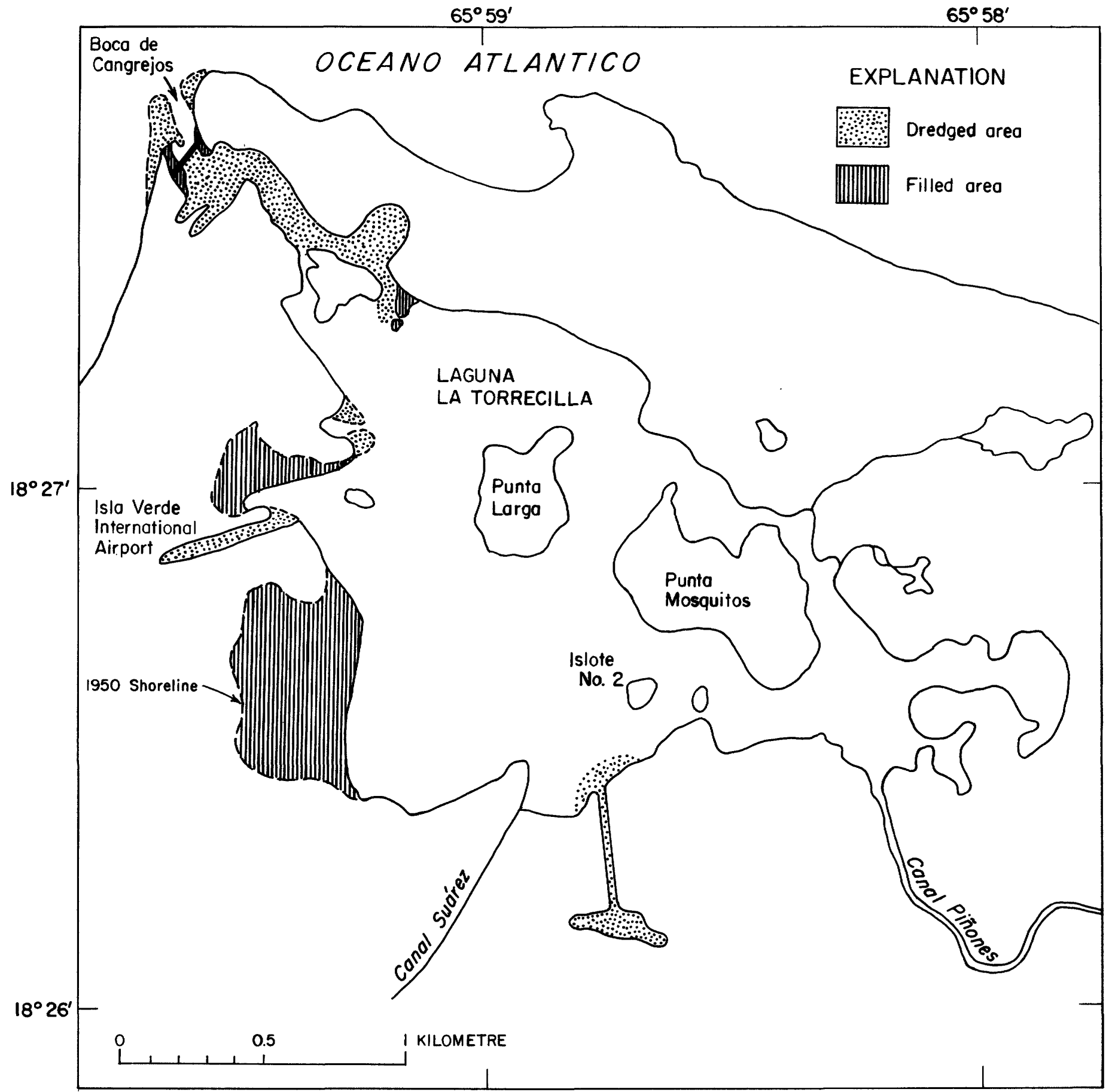

Base from U.S. Geological Survey

Carolina, 1: 30,000, 1950

Figure 7.--Areas dredged or filled from 1950-62 (Laguna La Torrecilla). 


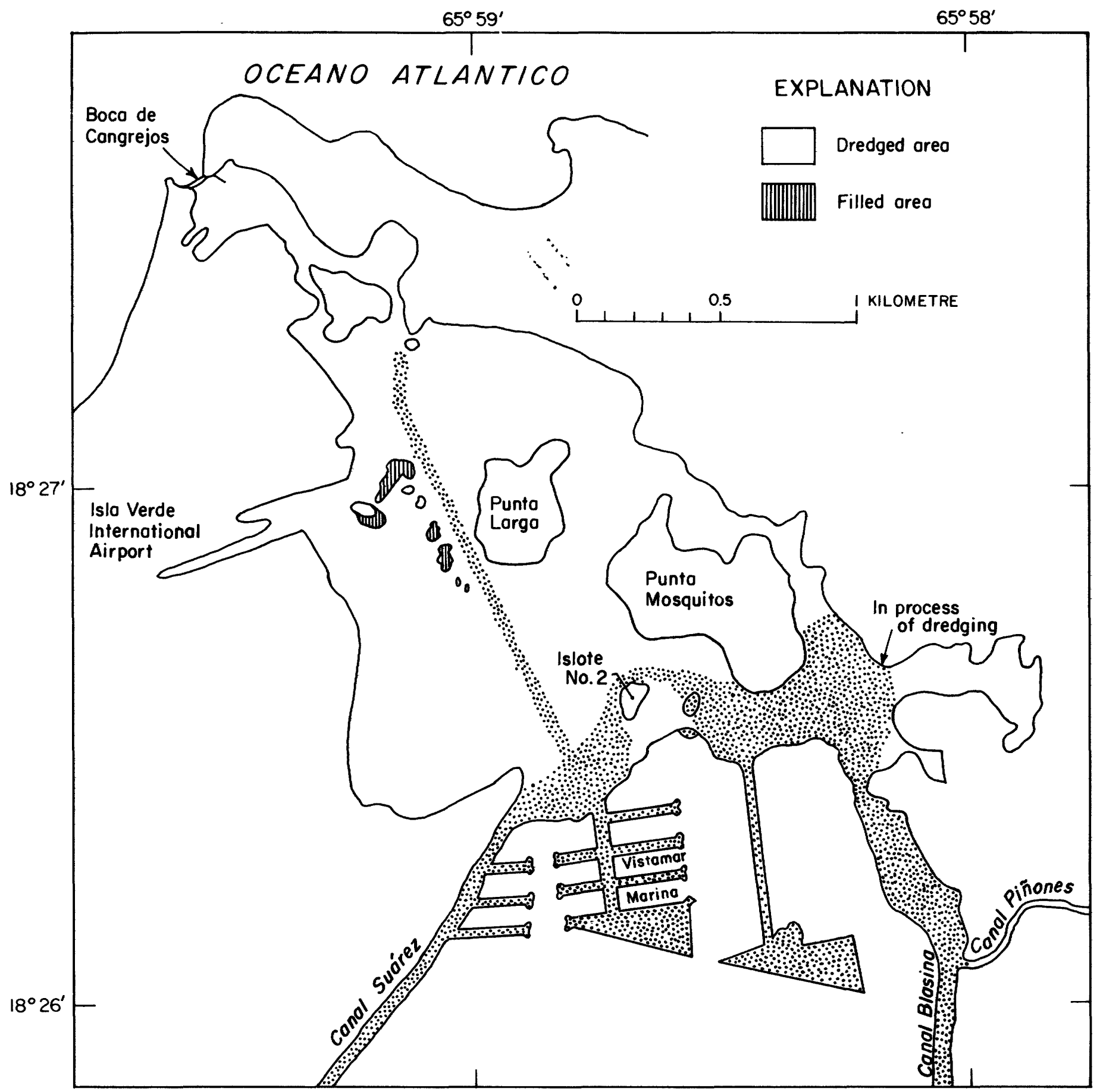

Base from U.S. Geological Survey

Carolina 1:20,000, 1969

Lagoon as of 1967

Figure 8.--Areas dredged or filled from 1962-67 (Laguna La Torrecilla). 
Dredging operations were in progress near the southeast edge of Punta Mosquitos when the September 25, 1967, aerial photographs were taken. This area was dredged to a maximum depth of about $16 \mathrm{~m}$. Laguna La Torrecilla, just north of Canal Piñones and Canal Blasina, was dredged to a maximum depth of about $7 \mathrm{~m}$ (fig. 2). Canal Blasina was formed when Quebrada Blasina was deepened and widened from the Highway 3 Bridge to Laguna La Torrecilla. The dredged depth of Canal Blasina is not known, but in 1971 it contained areas less than $1 \mathrm{~m}$ deep. The remaining area, that was dredged between 1962 and 1967, was a navigation canal about $3 \mathrm{~m}$ deep from Boca de Cangrejos to vistamar Marina (fig. 8). Small islands were formed, on the western side of the navigation canal near Punta Larga, from the dredged materials of shell fragments and sand.

Dredging operations continued near Punta Mosquitos into 1968, and an area east of Punta Mosquitos was dredged to a maximum depth of about $18 \mathrm{~m}$. This later dredging also modified the shoreline as some mangroves were removed. 1971 (fig. 9) all dredging and filling had ceased in Laguna La Torrecilla. The area near Boca de Cangrejos has had two additional marina bays for the yacht club, dredged from the mangrove swamp. One of these marina bays has not been developed as of January 1975; the other has floating boat slips and accommodates a large number of small yachts and boats. Two boat canals on the western side of Vistamar Marina have been filled for a housing development. The source of the fill was probably from dredging in the area south of Punta Mosquitos. Another change in the overall shape of Laguna La Torrecilla was the mangrove advancement into Islote No. 2, attaching it to the shore. It is not known if this shallow area was used as a spoils area thus promoting mangrove advancement or if this was a natural process.

Assuming the lagoon had a maximum natural depth of about $1 \mathrm{~m}$, the amount of material that has been removed is about 3.1 million $\mathrm{m}^{3}$. It is possible that the maximum natural depth may have been about $1.5 \mathrm{~m}$, but areas of these depths would be a small percentage of the total area.

Dredging has occurred in about 25 percent of the area of Laguna La Torrecilla (fig. 10) from 1950 to 1971. Dredging has increased the volume about 110 percent; whereas, filling along the edges reduced the area of the lagoon by about 10 percent.

Effects of the enlarging and deepening of ocean outlets may increase flow into estuaries (Keulegan, 1967). Increased interlagoon flow through Canal Suárez, between Lagunas La Torrecilla and San José, added to the flow through Boca de Cangrejos. The effects of dredging on the water renewal time of Laguna La Torrecilla is not known because both tidal flow and volume of the lagoon have been increased. Renewal time is considered as the time needed for a water body to completely renew its water. In simple form it can be expressed as $V / Q$, where $V$ refers to the lagoon's volume at low tide and $Q$ to the mean ebb tide volume discharged per day. An increase in tidal flow will increase the internal currents and dispersion within the lagoon. Dredging of Canal Blasina may have increased the tidal flow to Laguna de Piñones, causing the water renewal time of Laguna de Piñones to decrease. 


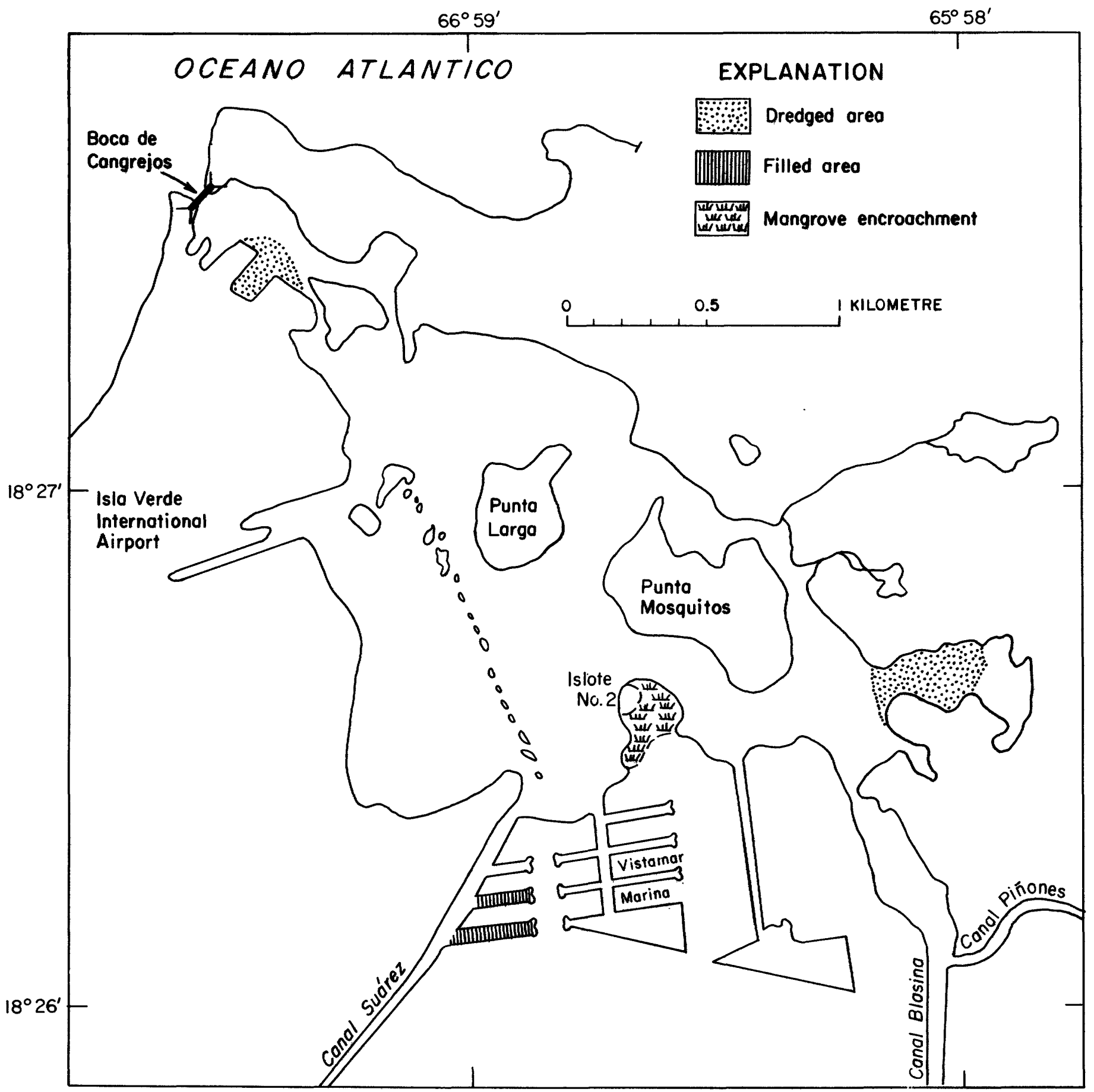

Base from U. S. Geological Survey Carolina, 1:20,000, 1969

Lagoon as of 1971

Figure 9.--Areas dredged or filled from 1967-71 (Laguna La Torrecilla). 


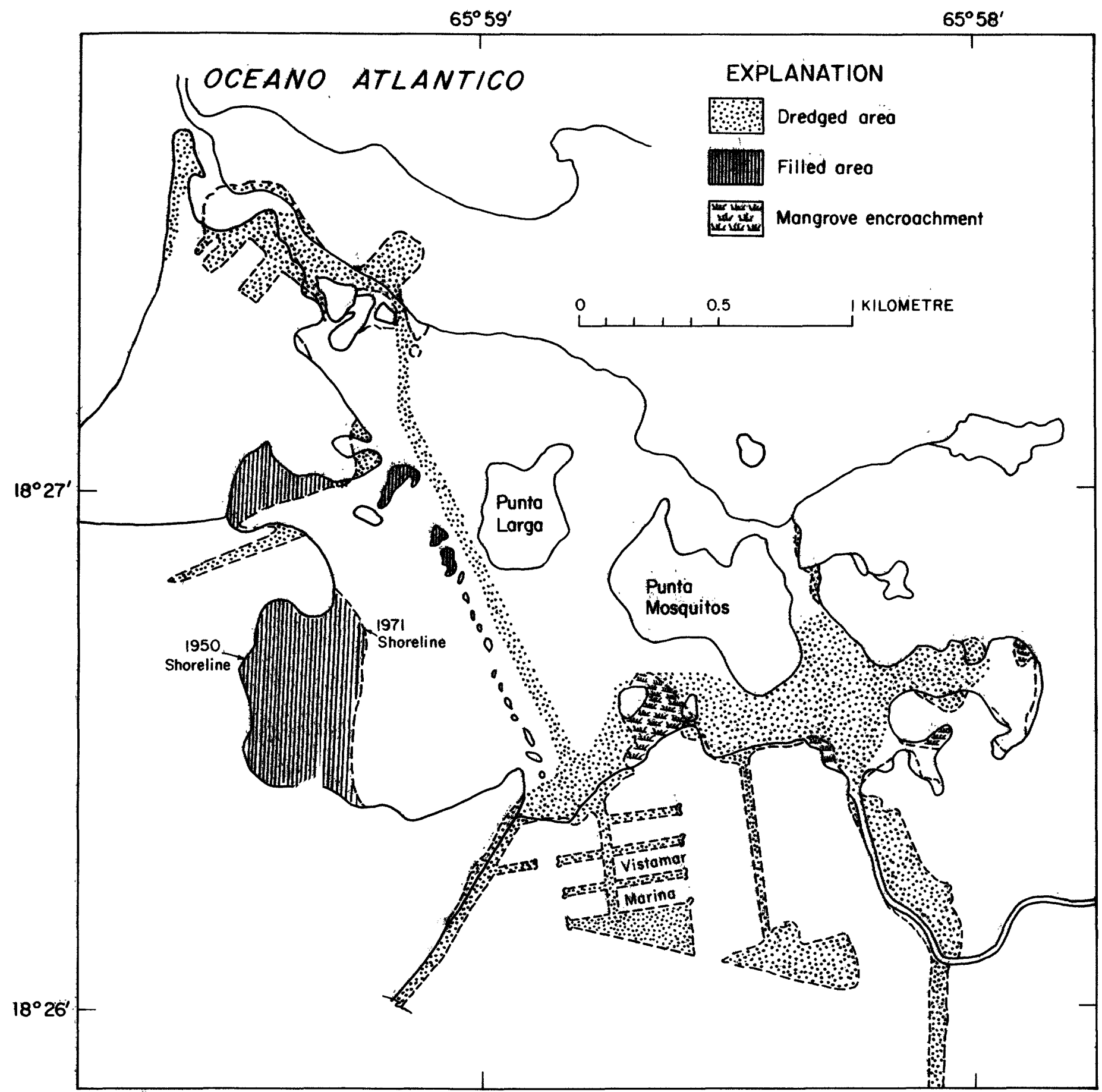

Base from U.S. Geological Survey

Carolina, I: $20,000,1969$

Laggon os of 1971

Corolina, 1:30,000, 1950

Figure 10.--Comparison of 1950 and 1971 shorelines and areas of internal dredging of Laguna La Torrecilla. 
The dredging of Boca de Cangrejos and the navigational canal to Vistamar Marina has probably affected the water quality in the surrounding areas of the lagoon. Although the area north of Vistamar Marina receives urban runoff and outflow from Laguna San José, anaerobic conditions have not been observed during a study by Elli is and Gómez-Gómez (1976b). Apparently the navigation canal provides a means for the higher density seawater to reach this area on incoming tide. The incoming seawater apparently brings DO (dissolved oxygen) into the deeper areas and removes the suspended solids with the outgoing tide.

The deep dredged area of Laguna La Torrecilla east of Punta Mosquitos and north of Canal Blasina (fig. 11 ) is persistently anaerobic below $2 \mathrm{~m}$, and has had $\mathrm{BOD}_{5}$ values (biochemical oxygen demand, 5-day) in the range of $50-190 \mathrm{mg} / 1$ (milligrams per litre). The anaerobic area was delineated by Do traverses (Ell is and Gómez-Gómez, 1976b).

BOD5 is the measurement of the amount of DO consumed by microbial life and chemical reaction while assimilating and oxidizing (decomposing) the organic matter present, as measured by dark incubation at $20^{\circ} \mathrm{C}$ (Celsius) for 5 days.

The dredged areas form pockets that trap higher density seawater that moves along the bottom of the lagoons. Tidal current and wind action are not sufficient to produce mixing with incoming freshwater in the deeper holes and, as a result, a density stratified water column exists. This stratification is shown in figure 12 for sites 4 and 5 , as detected by specific conductivity measurements (Ellis and Gómez-Gómez, 1976́b). Once density stratification develops at a site, vertical diffusion of oxygen is for practical purposes nonexistent. During the lagoon study, no DO was observed below the 2-m depth at these sites. Water from Canal Blasina, containing low or no DO and a high biochemical oxygen demand, enters Laguna de Piñones affecting that lagoon's water quality.

These anaerobic zones serve as nutrient traps and also as generators of nutrients needed by aerobic organisms. Among the basic nutrients for living organisms is phosphorus. In aerated zones, this element may exist as ferric phosphate or as calcium phosphate (Hutchinson, 1957). The relative proportions of each are controlled by the redox potential, $\mathrm{pH}$, and concentration. Besides these inorganic forms, a major portion of the phosphorus found in water is in the seston. All these compounds and organic matter slowly settle through the water column and undergo different transformations in the sediments. The end result is that the sediments become enriched in phosphorus, as is the case in these lagoons (Ellis and Gómez-Gómez, 19766). When anaerobic conditions develop, hydrogen sulfide--a by-product of organic decomposition--and ammonia are formed. The sulfide readily reacts with metallic phosphorus compounds, thus releasing orthophosphorus $\left(\mathrm{HPO}_{4}\right)^{-}$in solution. Within the water column, the reaction occurs as long as suspended matter (reactants) continues to precipitate or settle from the surface. This supply of organic matter is provided by detritus from the surrounding mangroves, runoff, and the dense algal population in these waters. The mean algal cell count (log mean), for samples taken at $0.5 \mathrm{~m}$ from the surface on seven different months at station 4 in Laguna La Torrecilla, was $4,800 \mathrm{cellls} / \mathrm{ml}$ (U.S. Geol. Survey, unpub. data). 


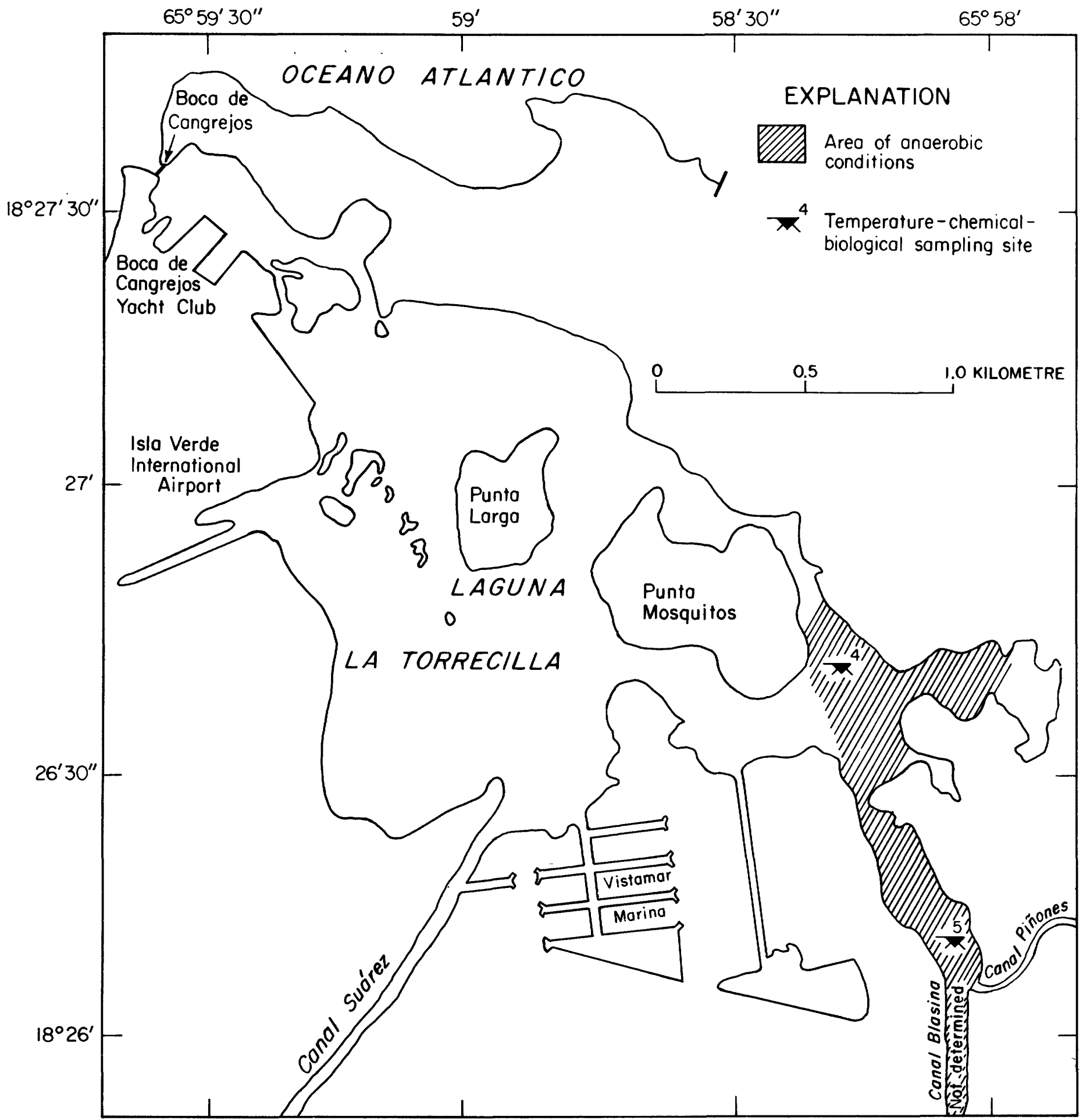

Base from U.S. Geological Survey

Carolina, 1:20,000, 1969

Lagoon as of 1971

Figure 11.--Anaerobic areas of Laguna La Torrecilla. 


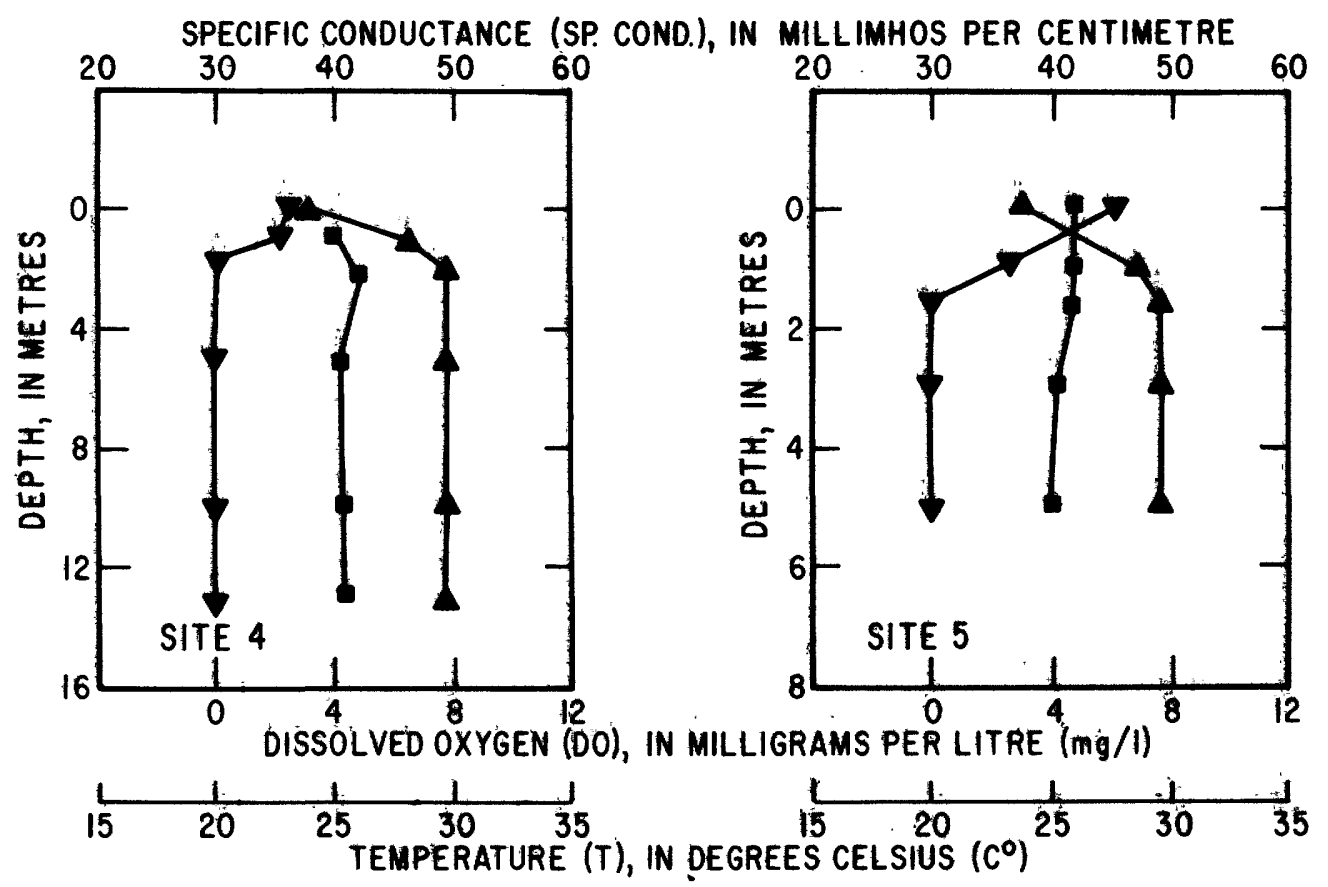

\section{EXPLANATION}

$\nabla$ Dissolved oxygen

- Temperature

- Specific conductance

Figure 12.--Profiles of dissolved oxygen, temperature and specific conductance for two sites in Laguna La Torrecilla which are anaerobic below 2 metres (see fig. 11 for location of sites).

At station 4 in Laguna La Torrecilla (fig. 11), evidence of phosphate and ammonia generation were obtained. The table below shows analyses for samples taken at depths of 0.5 and $12 \mathrm{~m}$.

Values Obtained at Laguna La Torrecilla Station 4

Date Time Depth (m) $\mathrm{NH}_{4}$ as $\mathrm{N}(\mathrm{mg} / \mathrm{l})$ 0-PO4 as $\mathrm{P}(\mathrm{mg} / \mathrm{l})$

\begin{tabular}{|c|c|c|c|c|}
\hline June 25 & $\begin{array}{l}0825 \\
0826\end{array}$ & 12.5 & 10.53 & $\begin{array}{l}0.55 \\
1.8\end{array}$ \\
\hline Aug. 12 & $\begin{array}{l}0855 \\
0856\end{array}$ & $12^{.5}$ & 1.5 & $\begin{array}{l}1.2 \\
2.5\end{array}$ \\
\hline Sep. 18 & $\begin{array}{l}0845 \\
0846\end{array}$ & $12^{.5}$ & $13^{.85}$ & 2.6 \\
\hline Nov. 7 & $\begin{array}{l}0800 \\
0801\end{array}$ & $12^{.5}$ & 13.7 & 2.47 \\
\hline Nov. 20 & $\begin{array}{l}0805 \\
0806\end{array}$ & $12^{.5}$ & $\frac{2.0}{16}$ & 2.91 \\
\hline
\end{tabular}




\section{Laguna San José}

The boundary of Laguna San José (fig. 13) has not changed noticeably, in comparing earliest known maps to the 1971 photographs. The alterations were usually made to the interior of the lagoon or to the canals. A Spanish map (National Park Service, written commun., 1975), about 1800, shows an apparently manmade canal in the northern end connecting Laguna de Martin Peña, known today as Laguna San José, directly to the Océano At lántico. Fray Iñigo Abbad y Lasierra makes reference to this ocean outlet and the danger of an attack on the bay in his geographic description of the area during his residence between 1771-78 (Abbad y Lasierra, 1788). Later maps do not show this entrance. The earliest known dredging was the construction of Canal Suárez during the 1800's.

The aerial photographs of 1951, 1962, 1967, and 1971 show a progression of dredging and filling in Laguna San José. The 1951 aerial photograph, the earliest available, shows a major canal dredged to Isla Verde International Airport, which probably was intended for drainage. This canal is not shown on the 1950 U.S. Geological Survey, 1:30,000 San Juan quadrangle. Two other minor drainage canals are visible on the 1951 aerial photographs.

The 1962 aerial photograph shows that the site of Laguna Gardens, a condominium development, had been cleared of mangrove and was in the process of being filled. This fill probably was dredged from Laguna San José, near the development (fig. 4).

The September 25, 1967 aerial photograph revealed dredging in process near the mouth of Quebrada San Antón. This area was dredged to a maximum depth of about $11 \mathrm{~m}$. The dredged material was probably used as fill for the area northeast of Quebrada San Antón. Canal Suárez had been widened and mangrove removed from both banks west of the Highway 26 Bridge. About 20 ha (hectares) of mangrove forest had been cleared. This area was filled to a height of about $1.5 \mathrm{~m}$ above mean water level.

By 1971 all dredging and filling had ceased. A public housing development on the peninsula north of Caño de Martin Peña had been built on landfill that probably was from the dredged area north of the peninsula. The fill was deposited to a height of about $1.5 \mathrm{~m}$ above the level of the lagoon. The dredged area covers about 2 ha and has a maximum depth of about $9 \mathrm{~m}$. This area is an isolated pocket surrounded by water less than $2.5 \mathrm{~m}$ deep.

Dredging has occurred in about 17 percent of Laguna San José (fig. 14), with about 3 million $\mathrm{m}^{3}$ of material removed. This volume was computed assuming that the maximum natural depth in the lagoon was $2.5 \mathrm{~m}$. Therefore, the volume contained below this contour on the bathymetric map was considered to be occupied by dredged material. Dredging has increased the volume of the lagoon by about 30 percent its original value. 


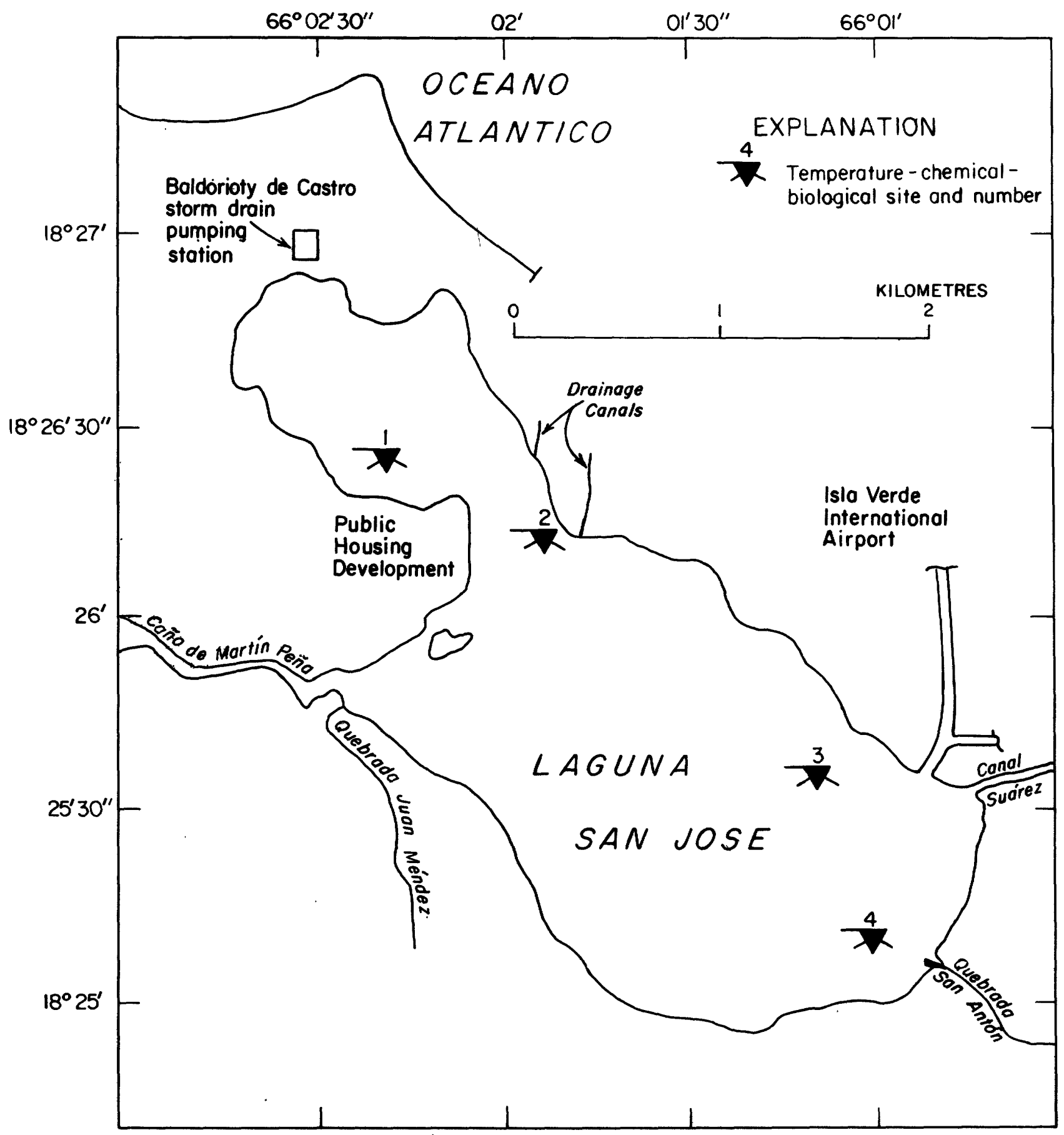

Base from U. S. Geological Survey

San Juan, 1:30,000, 1949

Lagoon as of 1971

Figure 13.--General features of Laguna San José in 1971. 


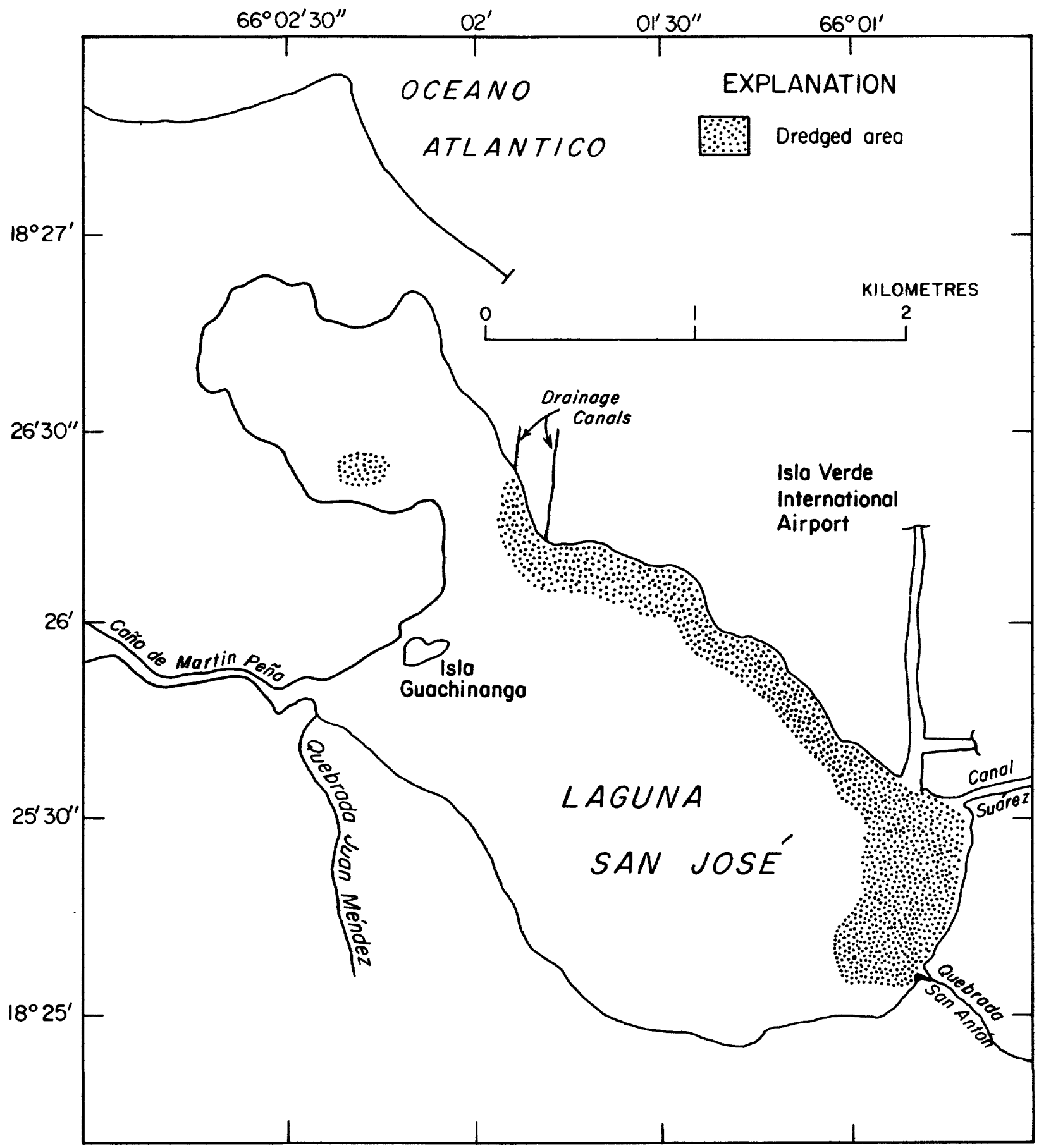

Base from U.S. Geological Survey

San Juan, $1: 30,000,1949$

Lagoon as of 1971

Figure 14.--Dredged areas of Laguna San Jose: 


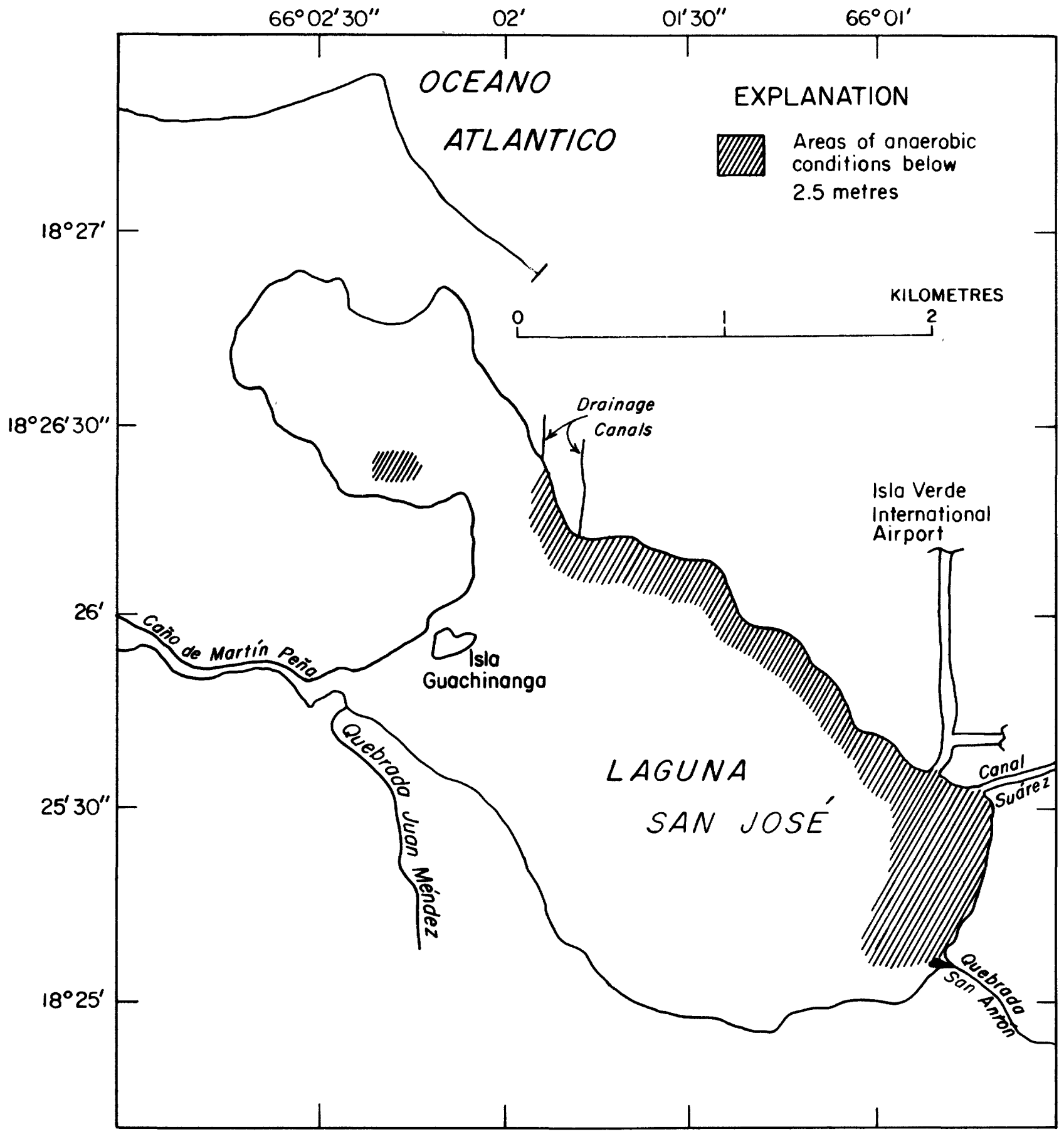

Base from U. S. Geological Survey

San Juan, I: 30,000, 1949

Lagoon os of 1971

Figure 15.--Anaerobic areas of Laguna San José. 
A major effect on the hydraulics of Laguna San José was the widening and deepening of Canal Suárez sometime between 1962 and 1967. Before these changes, Caño de Martin Peña may have been the main outlet of Laguna San José due to Canal Suárez' overall narrowness and shallowness. About 70 percent of the brackish water entering and leaving Laguna San José now flows through Canàl Suárez (Ellìs and Gómez-Gómez, 1976à). Enlargement of Canal Suárez probably has decreased the water renewal time of Laguna San José.

Principal point-source discharges affecting Laguna San José are: industrial chemical discharges into Canal Suárez and Caño de Martín Peña and effluent of a flood-control pumping station at the northwest. Raw sewage is discharged from substandard housing along Caño de Martín Peña affecting Laguna San José. $\mathrm{BOD}_{5}$ values, as high as $213 \mathrm{mg} / 1$, have been observed in the dredged areas of this lagoon (Ellis and Gómez-Gómez, 1976a). As determined by traverses, the dredged areas contain water with specific conductivity of about $20 \mathrm{millimhos} / \mathrm{cm}$ above a depth of about $2 \mathrm{~m}$ and about $40 \mathrm{millimhos} / \mathrm{cm}$ below about $2.5 \mathrm{~m}$. The difference in density (as indicated by specific conductivity) and the high $\mathrm{BOD}_{5}$ combine to produce stratification and anaerobic conditions below about $2.5 \mathrm{~m}$ ( $\mathrm{fig}$. 15). Graphs of the profiles of DO, temperature and specific conductance in the dredged and surrounding areas are shown in figure 16.

The effects of anaerobic conditions on phosphorus and ammonia regeneration into aerobic zones were covered in the section of Laguna La Torrecilla and are applicable to the anaerobic areas of Laguna San José.

\section{Laguna del Condado}

Laguna del Condado (fig. 17) was the first lagoon in the area to be altered by man. As early as 1625 (Puerto Rico Reconstruction Authority, 1940), the Spanish had constructed a bridge between the island of San Juan and what is now the Condado district of San Juan. During the 18 th century, the bridge was relocated to the present site of the Dos Hermanos Bridge.

A 1625 map shows two islands located about in the middle of the mouth of the lagoon. A small fort, San Gerónimo (fig. 17), was built from these islands extending to the western shore, blocking flow except for a small opening. In about 1797, Spanish engineers allegedly placed rocks across about one-half of the remaining opening for further protection (Kaye, 1959). The effect probably accounts for the shallow area inside and on both sides of the mouth. Sand deposition in the area now occupied by the Avenida Ashford Bridge and causeway seems to have always occurred as may be seen in maps as early as the 1600's (archives of the National Park Service, Fort San Cristóbal, San Juan). 

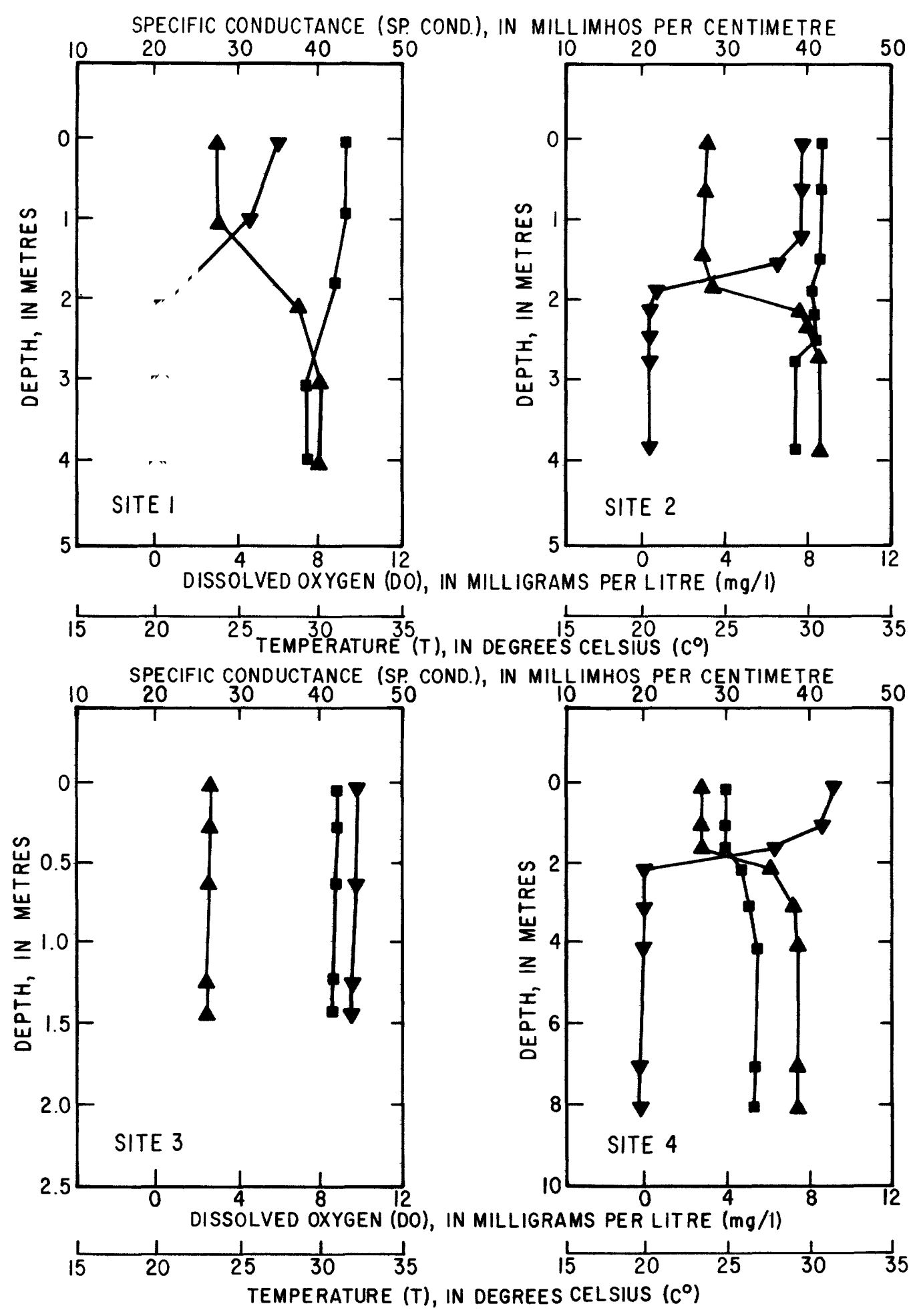

EXPLANATION

$\nabla$ Dissolved oxygen

- Temperature

- Specific conductance

Figure 16.--Profiles of dissolved oxygen, temperature, and specific conductance at selected sites in Laguna San José (see fig. 13 for location of sites). 


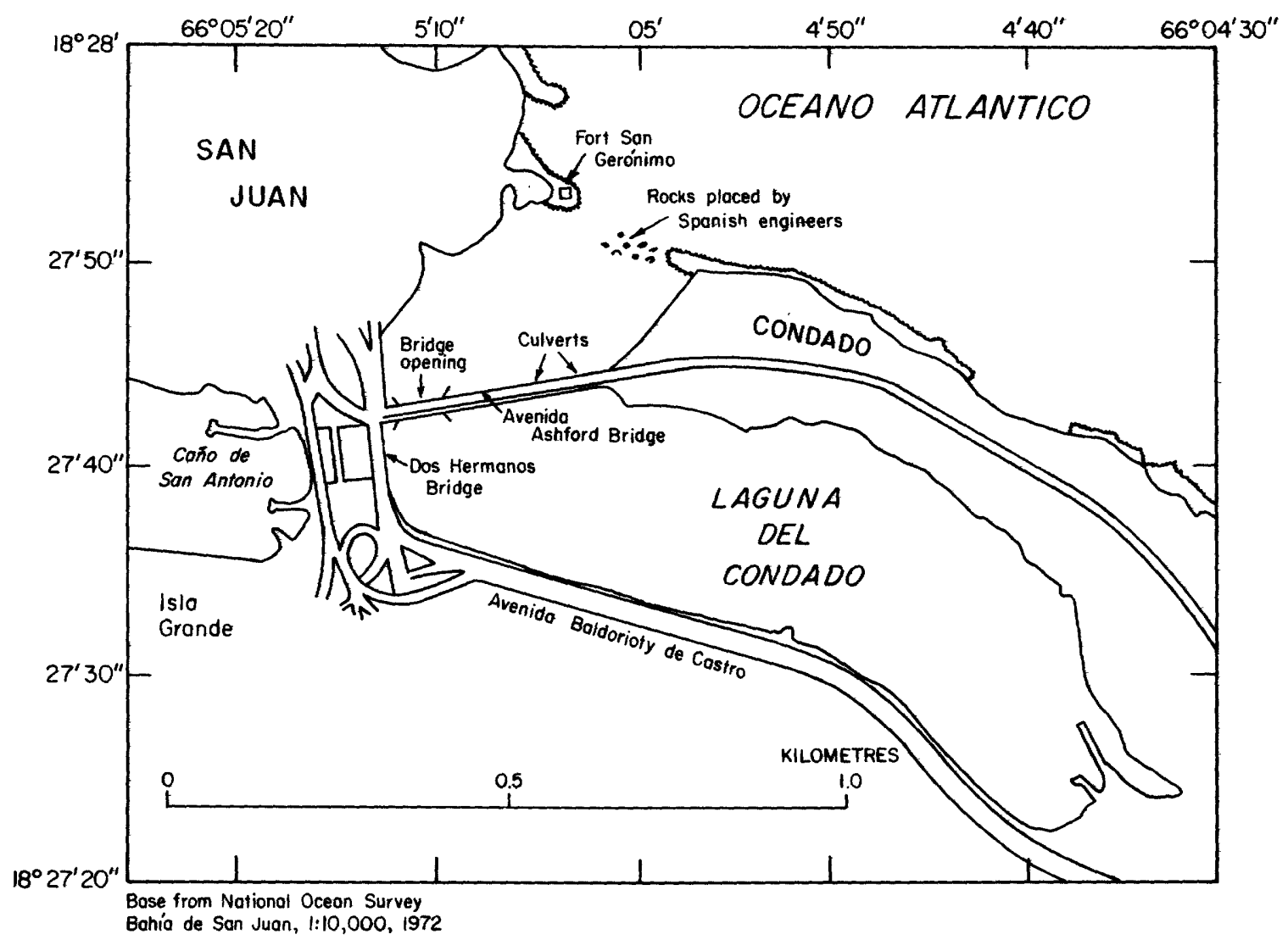

Figure 17.--General features of Laguna del Condado in 1972.

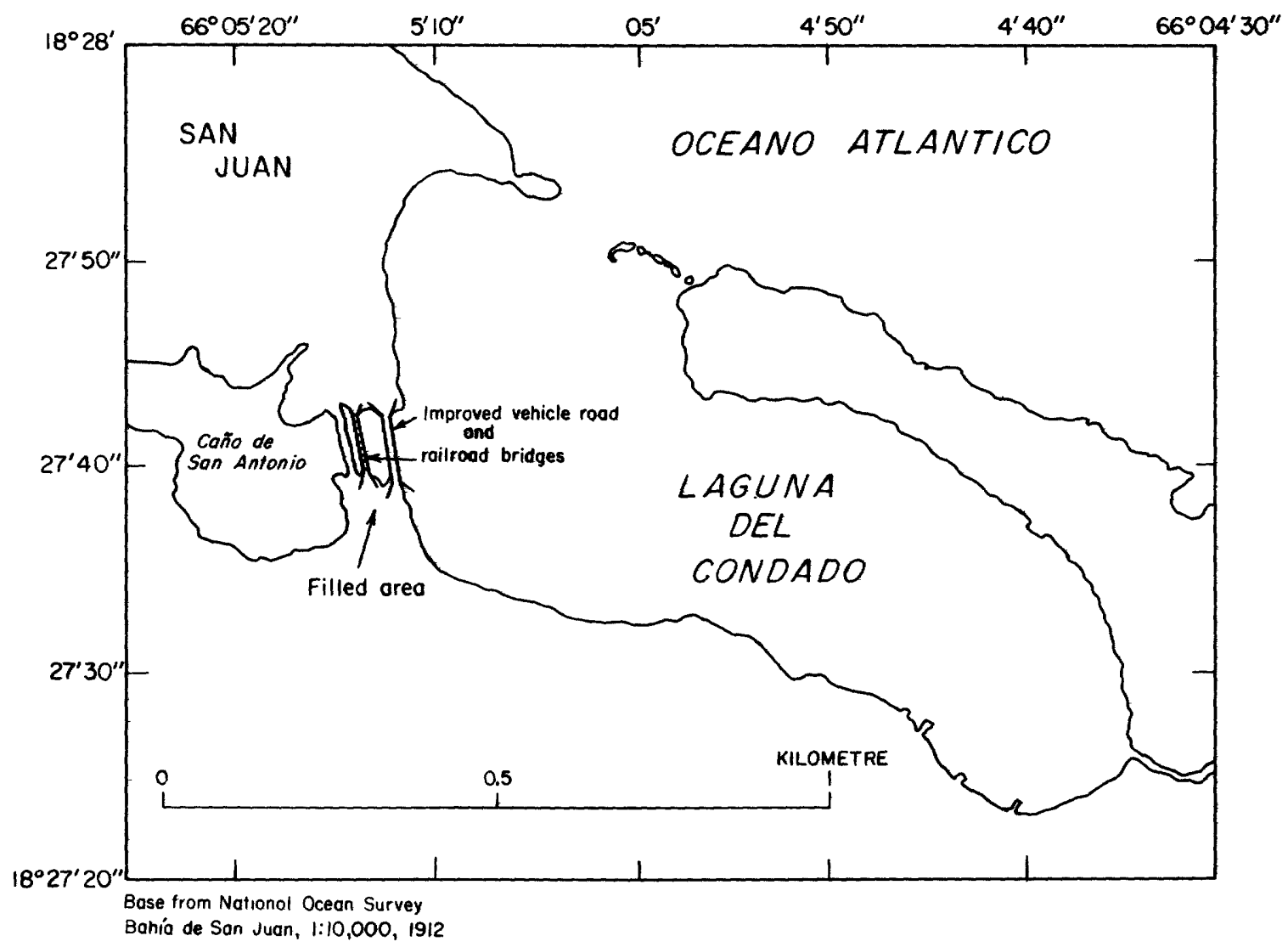

Figure 18.--Laguna del Condado in 1900. 
A map of 1900 ( $\mathrm{fig}$. 18) shows the construction of two railroad bridges and an improved vehicle bridge across Caño de San Antonio. This construction probably decreased the flow from Laguna del Condado to Caño de San Antonio because the south side of Caño de San Antonio was filled for about $100 \mathrm{~m}$. The filling of the canal and placement of piers for the bridges probably reduced the open water width to about one-half the original width.

During the 1920's additional changes occurred in Laguna del Condado. Construction of Avenida Ashford Bridge, with accompanying filling for a causeway on the Condado side, divided the orignial lagoon into two parts. The area of the present Laguna del Condado is about 31 ha; whereas, the area of the former lagoon before construction of the bridge was about 50 ha.

Avenida Ashford Bridge and causeway is about $500 \mathrm{~m}$ long; about $400 \mathrm{~m}$ is filled causeway. The causeway contains two openings each about $4 \mathrm{~m}$ wide. These openings were observed in January 1974 (Ellis and Gómez-Gómez, 1976a) to have flows of less than $0.03 \mathrm{~m} / \mathrm{s}$ (cubic metres per second) each. The bridge opening, about $100 \mathrm{~m}$ wide, is located on the west end of the causeway. The flow through this opening is almost always into the lagoon with no relation to tide stage. Ellis and Gómez-Gómez (1976a) found during a tidal-cycle study that the one-directional flow occurs when under prevailing northeasterly winds, a wind-induced current is generated. This current moves into the lagoon by the Avenida Ashford Bridge and out by the Dos Hermanos Bridge, regardless of the tidal stage.

The old bridge across Caño de San Antonio was rebuilt during the 1920's, and a new bridge was built about $50 \mathrm{~m}$ west of the original bridge. Some filling on the south bank occurred.

Another change was the construction of Isla Grande (fig. 1) by the Department of War, during the 1920's to 40's. Fill from the dredging and widening of Caño de San Antonio was used to build the large peninsula, which still bears the original name of Isla Grande.

In the late 1950's, the south side of Laguna del Condado was filled when Avenida Baldorioty de Castro was constructed. This fill was probably dredged from the lagoon. At this time riprap was placed along the south shore.

In the early 1960's, the last changes to Laguna del Condado occurred when the north shore was filled. Large tourist hotels, restaurants and night clubs were constructed on this area. The fill for the construction reportedly came from dredging in the east end of Laguna del Condado.

Using old maps as a reference, the maximum natural depth of the lagoon was estimated to be less than $7 \mathrm{~m}$. Assuming $7 \mathrm{~m}$ to be the predredged maximum depth, an estimated $200,000 \mathrm{~m}^{3}$ of material was removed from the lagoon. It is possible that some material not accounted for was removed from shallow areas, which were not dredged below $7 \mathrm{~m}$. The areas presumed dredged cover 20 percent of the total area of the lagoon. 
The hydraulic effects of filling, bridge construction, and dredging of Laguna del Condado (fig. 19) probably decreased circulation and increased renewal time. The construction of Avenida Ashford Bridge and Fort San Gerónimo, and placement of the rocks to block the entrance to the lagoon may have caused a decrease in the effectiveness of the wind generated current in mixing Laguna del Condado's waters. These three manmade changes probably are the main reasons for reduced circulation in the lagoon.

Another effect on the water quality of Laguna del Condado was the discharge of raw and partly-treated sewage until 1974. In the deep zones, the sewage created large areas of anaerobic conditions (Environmental Protection Agency, 1971). However, the lagoon has recovered to a more desirable state with little or no anaerobic areas because most of the sewage outfalls have been removed from the lagoon. As of December 1974 (Ellis and Gómez-Gómez, 1976a), no well established anaerobic areas existed in Laguna del Condado.

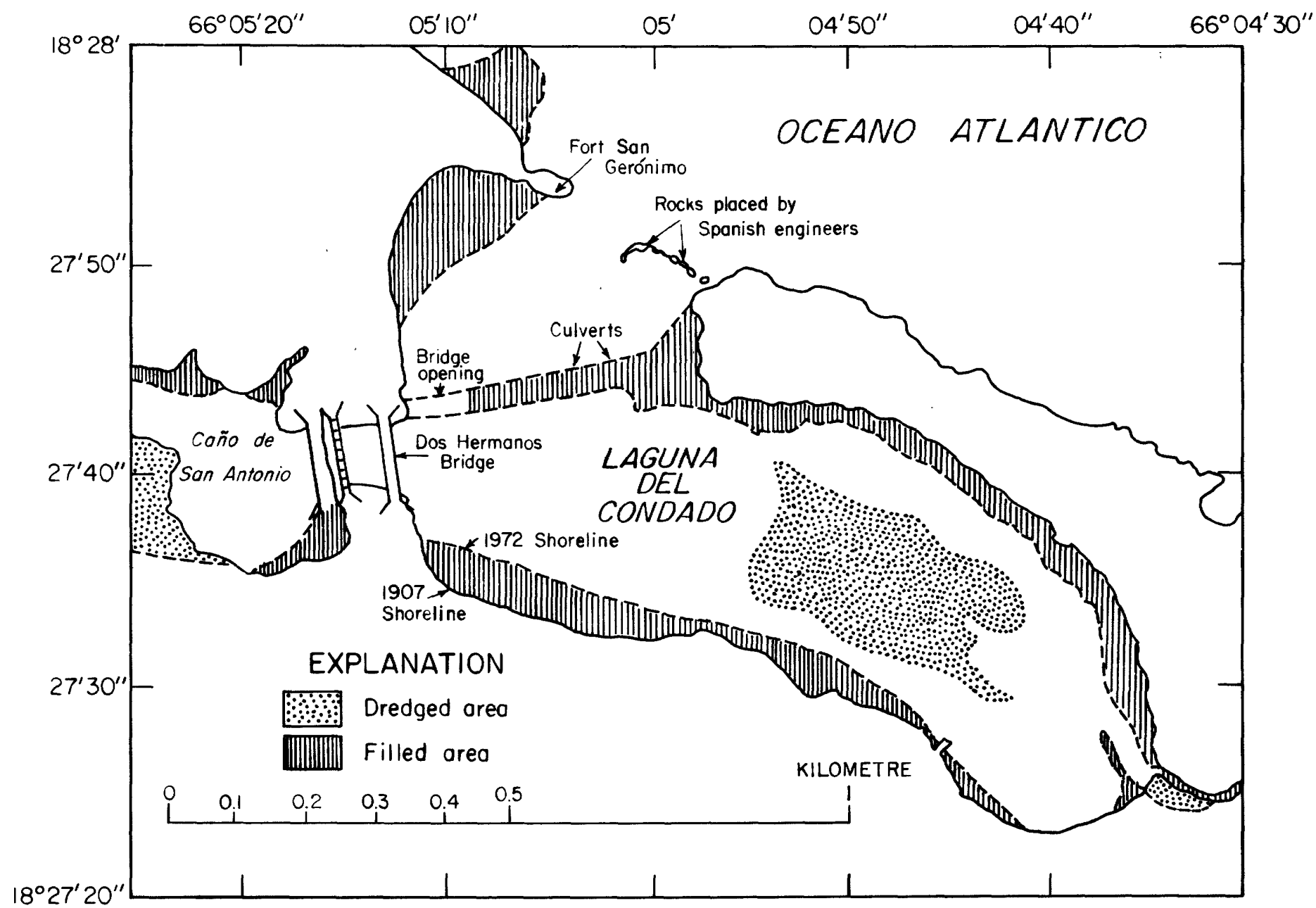

Base from National Ocean Survey Bahía de San Juan, 1:10,000, 1972 Bahía de San Jugn, 1:10,000, 1912

Figure 19.--Comparison of 1900 and 1972 shorelines and areas of internal dredging of Laguna del Condado. 
Dredging and filling have altered the shape and volume of Laguna La rrecilla. About 3.1 million $\mathrm{m}^{3}$ of material has been removed from the lagoon. dging has occurred in about 25 percent of the area of the lagoon and increasthe volume about 110 percent. The combination of dredging and the organic ading in the waters have produced a large anaerobic area in the southeastern d. This area acts as a trap of organic material and a nutrient sink, due to stagnant conditions. The anaerobic area through chemical reactions may nerate phosphorus and ammonia, as ions, into the water thus promoting algal isity increases. The $\mathrm{BOD}_{5}$ values in the anaerobic areas are as high as $\mathrm{mg} / 1$.

Dredging of Laguna San José has ocçurred in about 17 percent of the area of lagoon, removing about $3 \mathrm{million} \mathrm{m}^{3}$ of material. The dredging has increased volume of the lagoon about 30 percent. Construction of Canal Suárez has ated interlagoon flow with Laguna La Torrecilla. This interlagoon flow with iuna La Torrecilla may have decreased the water renewal time of Laguna San é. Sewage discharges, urban runoff, industrial effluents, and dredging have bined to produce anaerobic areas with $\mathrm{BOD}_{5}$ values as high as $213 \mathrm{mg} / \mathrm{l}$ below $2.5-\mathrm{m}$ depth.

Laguna del Condado was divided into two parts by the construction of Avenida ford Bridge. The bridge and causeway may have decreased effectiveness of al flow in mixing the waters of Laguna del Condado. Laguna del Condado, as 1974; shows few ill effects on water quality owing to dredging and filling. of December 1974 (Ellis and Gómez-Gómez, 1976a), no well established anaerobic. as existed in this lagoon. The dredging and filling operations probably have "eased its water renewal time. 


\section{SELECTED REFERENCES}

Abbad y Lasierra, Fray Iñigo, 1788, Historia geográfica civil y natural de la Isla de San Juan Bautista de Puerto Rico: repub. 1959, Univ. Puerto Rico, $320 \mathrm{p}$.

Anderson, H.A., 1976, Ground water in the San Juan metropolitan areas, Puerto Rico: U.S. Geol. Survey open-file rept.

Ellis, S.R., and Gómez-Gómez, Fernando, 1976a, Hydrologic characteristics of lagoons at San Juan, Puerto Rico, during a January 1974 tidal cycle: U.S. Geol. Survey Water-Resources Inv. 38-75, 45 p.

, 1976b, Water-quality and hydraulic data, San Juan lagoon system, Puerto Rico: U.S. Geol. Survey open-file rept.

Environmental Protection Agency, 1971, A study of coastal water quality in the vicinity of San Juan, Puerto Rico, January 13-31, 1971: Environmental Protection Agency rept., $41 \mathrm{p}$.

Environmental Research and Application, Division of Caribtec Laboratories, Inc., 1972, Dredging in Torrecilla-Piñones area: Environmental Impact Statement, San Juan, Puerto Rico, $140 \mathrm{p}$.

Hutchinson, G.E., 1957, A treatise on limnology: New York, John Wiley and Sons, Inc., v. 1, 1,015 p.

Kaye, C.A. 1959, Shoreline features and Quaternary shoreline changes, Puerto Rico: U.S. Geol. Survey Prof. Paper 317-B, $140 \mathrm{p}$.

Keulegan, G.H., 1967, Tidal flow in entrances, water-level fluctuations in communication with seas: U.S. Army, Corps of Engineers, Tech. Bull. 4, $89 \mathrm{p}$.

Puerto Rico Reconstruction Authority, 1940, A guide to the island of Borinquen: New York, Univ. Soc., Inc., 409 p. 